\section{Relationships of Wildlife to Livestock on Some Developed Ranches on the Laikipia Plateau, Kenya}

\begin{abstract}
RICHARD N. DENNEY1
Forestry Officer, Wildlife, Kenya Range Management Project, Food and Agriculture Organization of the United Nations, Nairobi, Kenya.
\end{abstract}

\section{Highlight}

The status and relationships of wildlife with domestic livestock on 42 ranches in the relatively developed ranching area of the Laikipia Plateau in Kenya, East Africa, were surveyed during 1967 and 1968. The average ranch was 35,400 acres, with approximately 3,000 cattle. Conservative estimates indicate a wildlife population of at least 100,000 animals of Thomson's gazelle size or larger, with some data being obtained on a total of 64 species. Most of the ranchers were tolerant of wildlife, in reasonable numbers, and except for certain species. The three most important wildlife-related problems were disease transmission, forage competition, and damage. Ranch practices which influenced wildlife were fencing (particularly game-proof fences), bush control, and shooting. The average rancher is interested in the possibility of a biologically sound, controlled game utilization scheme under which game meat could be sold. The potentials of expanded sport hunting and game cropping can make wildlife a profitable asset to the ranchers. Unless some means of assuring the landowner of a substantial return on the wildlife on his ranch is provided, the generally tolerant attitude prevailing now will deteriorate, and with it the status of the wildlife.

The Laikipia Plateau has been the home of wildlife and Masai livestock since long before the arrival of the first European. It has become one of the most important livestock areas in Kenya today. It may also be one of the last areas in which considerable numbers and varieties of wildlife will be found in the not too distant future, other than in game reserves and national parks, depending on the attitude of the ranchers toward wildlife and the resultant policies adopted in ranch management. These ranchers may become more tolerant, even genuinely concerned about the welfare of wildlife, if it can be shown that game has an intrinsic value to them. To better understand the relationships between wildlife and livestock it was necessary to assess the factors of livestock husbandry of these relatively well-developed highland ranches which affect and are affected by wildlife. This survey represents a beginning in such an evaluation.

\footnotetext{
1 Present address is Wildlife Consultant, The American Humane Association, P. O. Box 1266, Denver, Colorado, 80201 .
}

Due to the increasing settlement in some of the rangelands of Kenya through stabilizing nomadic pastoral groups by land adjudication and grazing schemes, many of the principles evolved through almost 50 years of ranching experience in Laikipia can have immediate application.

Information and data concerning natural features, the type and extent of improvements, livestock data, management practices, and the attitude toward wildlife, as well as seasonal estimates of game numbers, wildlife-livestock disease relationships, competition, damage and wildlife utilization and values were obtained from 42 ranches in Laikipia.

\section{Location and Study Area Description}

The Laikipia Plateau is an area in west central Kenya lying west and north of Mount Kenya, from just south of the equator to $0^{\circ} 45^{\prime}$ north latitude and between $36^{\circ} 15^{\prime}$ and $37^{\circ} 10^{\prime}$ east longitude (Fig. 1). It is characterized by relatively low and erratic annual rainfall, which dictates a grazing or ranching economy. The area as a whole is com- prised of 1,869,000 acres, of which approximately $92 \%$ is uncultivatcd meadows and pasture (Kenya M.E.P. and D., 1965). The greater part lies on the rolling plains drained by the Ewaso Nyiro and Ewaso Narok rivers and their tributaries. Altitudes vary from 4,500 feet in the lower Ewaso Nyiro to 7,500 feet in the foothills of the Aberdare Mountains, with the bulk of the plateau lying between 5,500 and 6,500 feet.

\section{Climate}

Although located practically on the equator, this area is characterized by moderate temperatures, relatively low humidity and a low, erratic annual precipitation. Daily temperatures have a maximum of $79 \mathrm{~F}$ and minimum of $45 \mathrm{~F}$, with a mean annual temperature of $59 \mathrm{~F}$.

The average annual rainfall ranges from 18 inches on the lower Ewaso Nyiro to 32 inches on the slopes of the mountains, with an overall average of 25 inches. Approximately $32 \%$ of the rainfall is received during the March through May period, 21\% during July and August and 20\% during October and November. The July-August rains, locally termed the "grass rains," are more pronounced toward the western side of the Laikipia Plateau.

Water is a limiting factor in the plateau, but the Ewaso Nyiro and the Ewaso Narok, with many of their tributaries draining the Mount Kenya and Aberdare Mountains watersheds, provide yearround water. Other drainages provide seasonal or temporary water, and natural springs occur in some areas, particularly at the northwest end of the plateau. Swamps and lowlands have been channelled to provide water, and reservoirs of various sizes, along with boreholes (wells) provide much of the water for livestock.

\section{Vegetation}

The rangeland comprising the Laikipia Plateau is mostly characterized by a semi-arid climate. The land is of marginal agricul- 


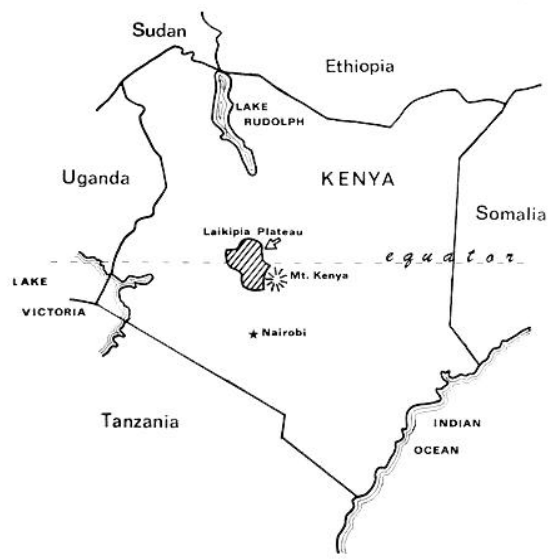

FIg. 1. Location of the study area, the Laikipia Plateau, Kenya, East Africa.

tural potential with a natural vegetation of dry forms of woodland and savanna, primarily an AcaciaThemeda association. It is a potentially productive range, limited by the encroachment of bush; and, while sensitive to severe grazing, burning is usually part of its management. Usually less than 10 acres are required per stock unit.

Second is rangeland with an arid climate. Here only local limited areas are suited to agriculture, with shrubby-type woody vegetation dominating. Desirable perennial grasses can dominate, although highly susceptible to overgrazing. More than 10 acres are required per stock unit.

The vegetative types are basically grassland, bushed grassland, wooded grassland and woodland, the latter restricted to riverine conditions and higher elevations on the slopes of the mountains. Individual ranches varied considerably in the vegetative types represented, depending on local site features such as altitude, topography, soils and precipitation. Based on the acreages of the vegetative types on the ranches, $39 \%$ of the area is bush, $37 \%$ open grassland or plains, $14 \%$ savanna, $6 \%$ forest, riverine or steep slopes, and $4 \%$ heavy forest and bush mixed.

\section{Normal Characteristics of the Developed Ranch}

When the terms "owners" and "private land" are used in this paper they do not refer to freehold or titled land, but rather to land on leaseholds under which practically all the land in Kenya is held, usually on a 999-year lease. The ranches ranged from 8,000 to 128,000 acres, with an average size of 35,400 acres. Carrying capacities ranged from 6 to 24 acres per animal unit per year, with an average of 10.9 acres. Stocking rates varied from 6 to 20 acres, with a mean of 11.4 acres per head. Compared with the average carrying capacity it appears the plateau is generally within the indicated carrying capacity.

The ranching economy is basically beef production, with an average of 3,000 head, comprised of $65 \%$ Boran and 23\% Boran crosses. Many ranchers have highgrade exotic bulls (Bos taurus), but some are turning to artificial insemination to produce controlled crosses. Although sheep were among the first livestock introduced in Laikipia by Europeans, they have never gained the prominence that cattle have. Seventyseven per cent of the 62,500 sheep found on 25 ranches are the woolproducing Merino breed.

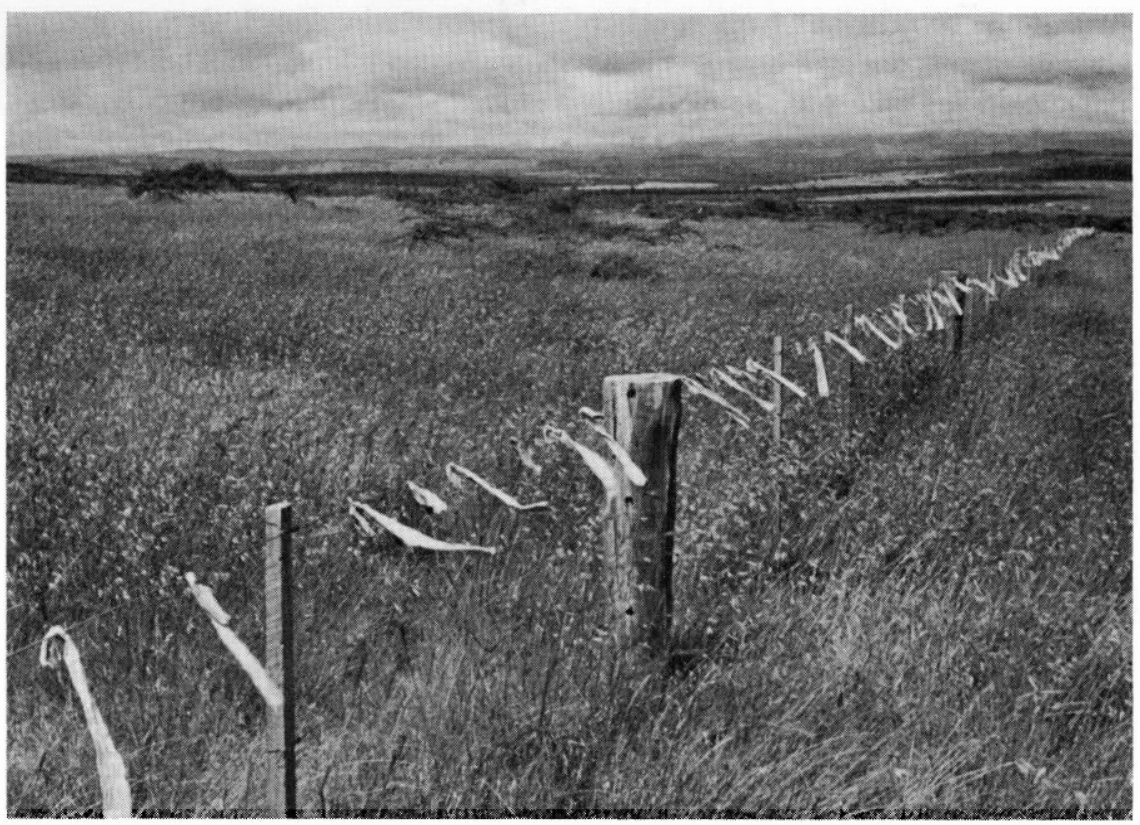

FIG. 2. Simple measures, such as strips of red and white cloth tied to the top wire, have been used to scare game away; in this case, to keep zebra out of a newly-fenced paddock.
Management, production, and range improvement are directly proportional to development in most cases. Paddocking into units consistent with the size of the ranch and system of grazing, and with water available in each paddock, is the desired objective. Based on an arbitrary classification considering perimeter fencing and paddocking, as well as water development and the furthest that stock must travel to water, $60 \%$ of the 42 ranches are in stages of advanced development or are fully developed. The Ministry of Agriculture uses an estimate of 70 cents to $\$ 1.12$ per acre for water development.

Three ranches have none of their perimeter fenced, and there are 1,395 miles of ring-fencing on the other 39 ranches. Thirty-three ranches have interior fencing, with a mean of 32 paddocks averaging 900 acres. Five strands of smooth wire are used for general fencing; however, new ideas have been tried on special fences in relation to wildlife. Some of these involve game-proofing, while others aim to allow game passage without fence damage. One rancher built inter- 
nal fences after a two-year trial, consisting of three strands of smooth wire on posts 90 feet apart with four droppers. He has found that this effectively bars his mature cattle, while the flexibility allows large game to go through and the lowness allows them to jump over. Rather simple measures have been tried for short-term effect. When fencing a new paddock, one rancher hazed the zebra out before closing the last side, then tied strips of red and white cloth on the top wires for about three miles (Fig. 2). The material endured long enough to keep the zebra spooked out, but became faded and disintegrated in time. Buffalo and other forest wildlife grazed nightly on a ranch lying adjacent to the forest land at the north end of the Aberdares, causing destruction to existing fencing. A combination fence and ditch has been constructed along seven miles of ranch boundary adjacent to the forest to keep such wildlife out. The ditch is six feet deep, one foot wide at the bottom, seven feet wide at the top, and the dirt is piled three feet high on the ranch side of the ditch (Fig. 3). A four-strand smooth wire fence is built atop the dirt mound, with posts 30 feet apart with four droppers. Economically the rancher feels that the increase in forage adjacent to the forest will enable him to run more stock, which will compensate for the barrier cost of $\$ 1,120$ per mile.

While such a structure adequately protects one ranch, and may be justified economically, it then behooves adjacent ranchers, farmers and settlements and/or the government to link such systems with other similar structures or adequate natural barriers to prevent the funnelling of the diverted wildlife onto neighboring enterprises which may be of lower economic potential but nevertheless essential, such as settlement schemes on a subsistence basis. Twenty miles of game moat exist in the Nyeri area, separating forest and the Aberdare National Park

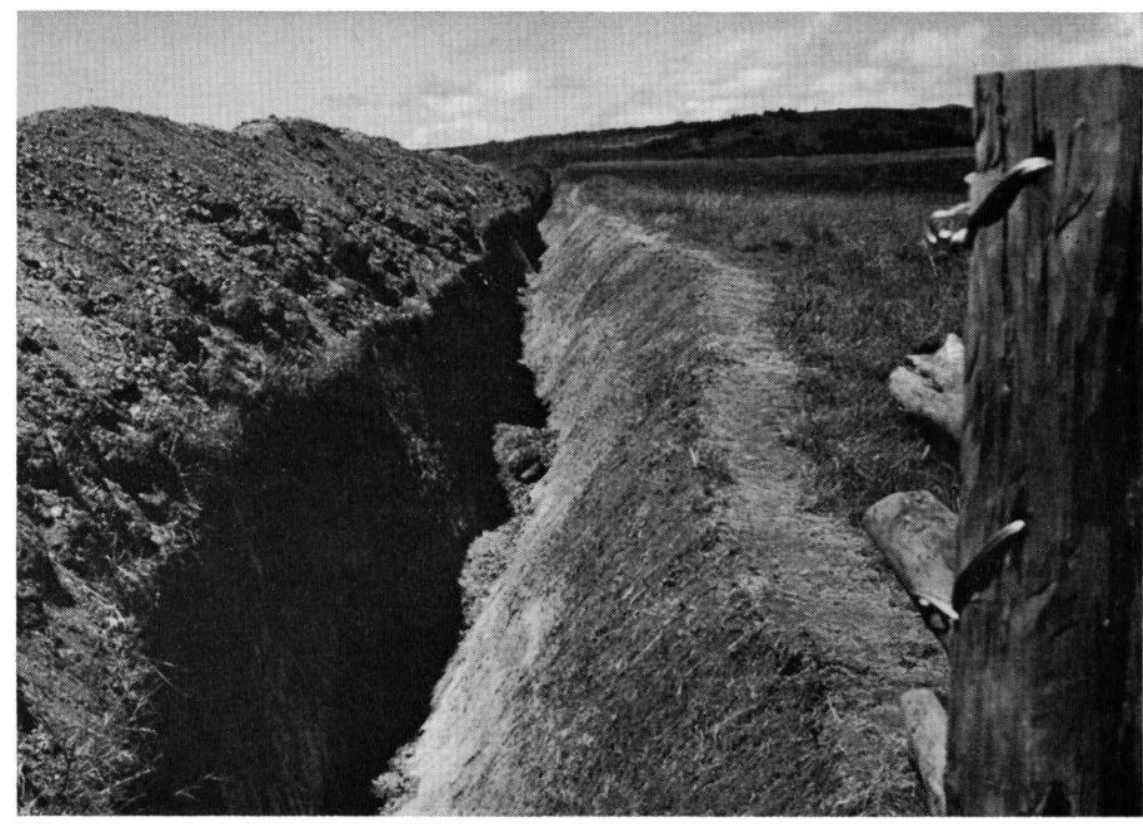

FIG. 3. Game-proof ditch and fence under construction, showing the dirt piled on the ranch side. A four-foot fence will be erected on the dirt and the ditch covered with cut bush.

from adjacent settlement schemes. The government plans to link this moat with the one described at the north end of the Aberdares over the next four years at an estimated cost of $\$ 2,464$ per mile, plus $\$ 280$ per mile maintenance costs per year.

Various other styles of gameproof fencing without the moat have been tried with some success. The Timau area was not included in the survey, but three ranches there have been blocked into a unit within a common perimeter fence against buffalo and elephant, as well as vermin (hyena, wild dog, jackal). This highly successful fence has been up six years, and consists primarily of heavy gauge wire netting up to five feet, with angled bracing to the outside from the tops of the posts which are strung with barbed wire. The cost was $\$ 980$ per mile, but the increased grass production in the pastures adjacent to the forest was felt to justify the cost.

Another type consists of chainlink or ring-lock wire, sometimes with part of the lower portion buried in the ground, with two or more strands of barbed wire on top, and may have one strand of barbed wire at ground level if the mesh is not buried. This type of fence is usually seven to eight feet high. However, one such fence enclosing approximately 23,000 acres to keep hyena and jackals out of sheep paddocks is about five feet high and heavy gauge wire netting was used at a construction cost of $\$ 1,000$ per mile (Fig. 4).

Fences utilizing chain-link, woven wire, wire netting or similar tight mesh usually preclude the entrance of most predators and allow their strict control within the enclosure. They also effectively block the movement of ungulates, the species affected being dependent to some extent upon the total height of the fence. Therefore, the extensive uncoordinated use of such structures could have serious implications in regard to unprotected neighbors and certain wildlife populations.

The seasonal abundance of ticks makes it necessary to keep livestock as free of them as possible through the use of dips or sprays. There is an average of one tick control device per 15,000 acres. Toxaphene is the tick control compound used 


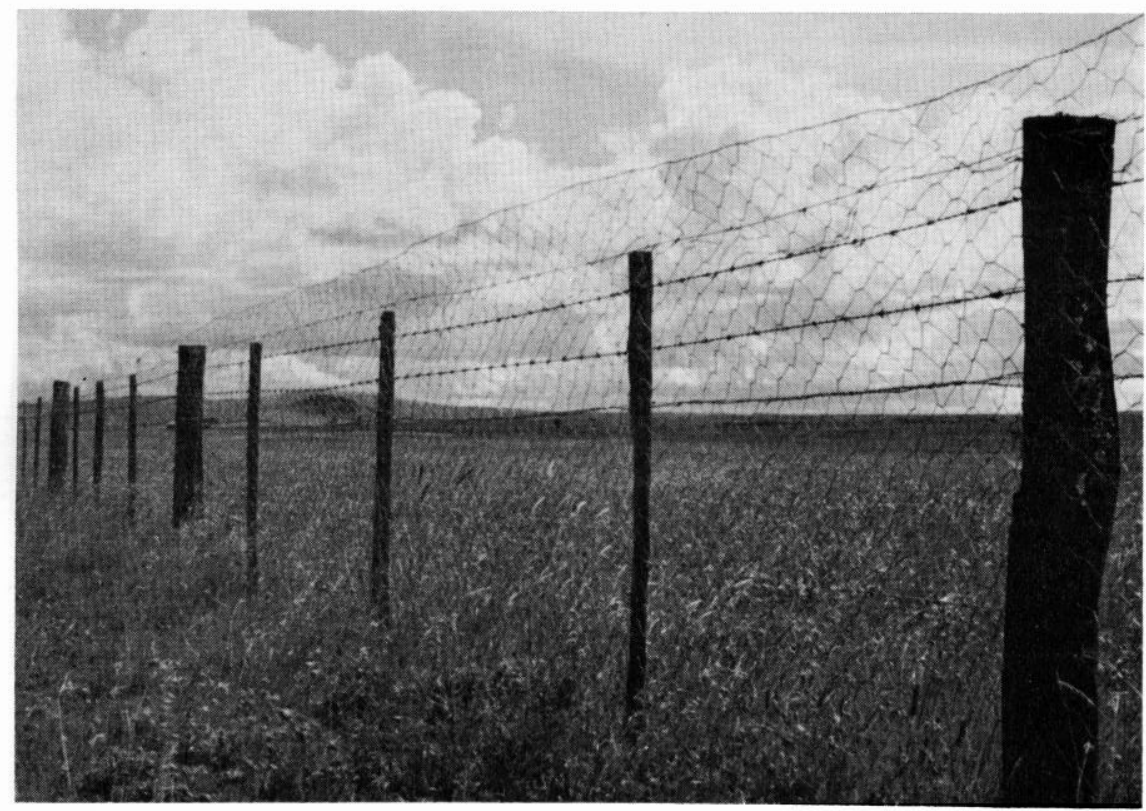

FIG. 4. Five-foot high wire netting fence to keep hyena and jackal out of a 23,000 acre area.

on $83 \%$ of the ranches, and dipping or spraying is performed during the tick seasons by most ranches at least fortnightly at an average cost of 3.5 cents per head per treatment.

Arable lands comprised only $0.3 \%$ of the area, being devoted to maize, lucerne and other fodder crops, but included 1,500 acres of wheat on one ranch. The bulk of the maize is for African labor.

Livestock can be grazed out throughout the year without supplemental feed. The paddocked ranches employ a flexible system of rotation similar to the decision deferment described by Hoffman et al. (1968), based on specific needs or situations, usually for an entire growing season or part of it when moisture conditions are best, and where systematic deferment cannot be applied economically. Some ranchers heavily graze a paddock and then rest it until it fully recovers. Some burning is still carried out, especially in the Acacia-Themeda zone, but not with any set frequency.

Slaughter animals are one of the main sources of income, and the study area ranch mean annual shipment was 468 steers, 108 heifers and 43 cull cows. The gross in- come per ranch from beef cattle and wool sheep averaged $\$ 67,236$ per year, or $\$ 1.90$ per acre.

\section{Livestock Mortalities and Control}

Death losses of livestock naturally decrease the productivity of a livestock enterprise, and necessary steps to alleviate such losses increase the operating costs. Disease losses on the 42 ranches ranged from 0 to $5 \%$, averaging $1.8 \%$, and with $40 \%$ of the ranches reporting less than $1 \%$. Total annual mortality ranged from 0.8 to $8.0 \%$, with an average of $3.2 \%$.

Based on the 123,000 cattle reported on these ranches, there would be a total annual death loss of almost 4,000 head, of which approximately 2,200 would be attributable to disease. One rancher stated that $80 \%$ of the disease in his cattle was due to tick-borne diseases. Another said that $25 \%$ of his disease mortality was due to anaplasmosis, and several other ranchers felt that most of their losses were due to this tick-borne rickettsial disease alone. Tick-borne diseases (anaplasmosis, heartwater, sweating sickness, redwater and East Coast fever), which may be implicated with wildlife, are gen- erally guarded against through tick control with toxaphene $(83 \%$ of the ranches, of which $17 \%$ use an organo-phosphate in combination). Other diseases as well, attributed by the ranchers to wildlife, are ondiiritis, rinderpest, foot and mouth disease, anthrax, lymphangitis, contagious bovine pleuropneumonia, leptospirosis, biliary fever, African swine fever, haemorrhagic septicaemia and blackquarter. Annual expenditures for prophylaxis and treatment of diseases and parasites by Laikipia ranchers, apart from dipping and spraying costs, average approximately $\$ 958$.

Livestock losses from accidents (broken legs, bloat, calving, etc.), plant poisoning and snakebite are of considerable magnitude (1.3\%). Predation by "vermin" accounts for mortalities approximating 1.2\%, and losses due to spearings and theft amount to $0.7 \%$. Losses in the first and third of these categories can be minimized to some extent by paddocking, and if a ranch isn't sufficiently developed the herding practices can alleviate some of these losses. Control of losses from predation is effected by shooting, the use of gin (steel) traps and live-traps, poison baits and, to some extent, herding practices. Gun traps used to be employed, but the majority of ranches use carcasses or kills poisoned with strychnine or toxaphene nowadays. Dogs are used extensively by some ranchers to flush, trail, and "tree" or bag predators such as lion, leopard, cheetah, hyena, and sometimes jackal.

\section{Wildlife}

\section{Rancher Attitude and Policy}

The quantity and species of wildlife present on a ranch, either as resident or migrant populations, may have considerable influence on the administrative policies and operational management of that ranch. In spite of this, however, $90 \%$ of the ranchers indicated a tolerant attitude toward wildlife generally, but not without certain qualifications, such as being toler- 
ant of reasonable numbers, and except certain species (variable, but including buffalo almost unanimously, and waterbuck, zebra, rhinoceros, eland, and lion). Of the 38 ranchers claiming tolerance, six proclaimed themselves essentially as protectionists. At the other extreme were two ranches with wildlife extermination policies, and two not quite so radical, but considered intolerant of wildlife. In four cases it was apparent that the attitude and administrative policy of the ranch ownership was not approved of or supported by the ranch manager.

Several ranchers remarked that ranching would be much easier and simpler if there was no wild- life, and in a few cases efforts to drastically reduce wildlife populations or exterminate them have been initiated. Fortunately, most of the ranchers who feel that their operation would be simplified without game still prefer to have them around for aesthetic or utility purposes.

Since the welfare of wildlife species depends so greatly on the attitudes of the ranchers toward them, and their resultant management policies, it is essential to maintain the tolerance of the ranchers who are tolerant, and to improve the attitudes of those who are not. In view of the expressed thoughts that wildlife adds to the general burden of ranch management, and to the costs incurred as discussed in the following sections, it would appear that wildlife must pay its own way to maintain tolerance or decrease antipathy. Therefore, it is clear that wildlife must contribute further to the economy of these developed ranches to insure proper game management.

\section{Wildlife Species and Numbers}

Sixty-eight species of wild animals were listed as occurring on the 42 ranches, some of which, however, are insignificant economically or are of such low densities as to occur on few ranches. The estimated populations, where applicable, are based entirely on guesstimates by the ranchers, although a

Table 1. Population data for important wildlife species on forty-two Laikipia Plateau ranches, $1967-68$.

\begin{tabular}{|c|c|c|c|c|c|c|}
\hline \multirow[b]{2}{*}{ Species } & \multicolumn{2}{|c|}{$\begin{array}{l}\text { Number of ranches } \\
\text { on which present }\end{array}$} & \multicolumn{4}{|c|}{ Populations } \\
\hline & Resident & Seasonal & Resident & Seasonal & Mean & Total \\
\hline Baboon, yellow (Papio cynocephalus) & 11 & 20 & & & 425 & 4,600 \\
\hline Buffalo, cape (Syncerus caffer) & 22 & 34 & 108 & 133 & 120 & 3,330 \\
\hline Bushbuck (Tragelaphus scriptus delamerei) & 21 & 30 & 58 & 70 & 64 & 1,310 \\
\hline Cheetah (Acinonyx jubatus) & 22 & 30 & 11 & 14 & 12 & 300 \\
\hline Duiker (Cephalus monticola, C. natalensis) & 19 & 32 & & & 71 & 1,360 \\
\hline Eland (Taurotragus oryx pattersonianus) & 20 & 34 & 155 & 201 & 178 & 3,000 \\
\hline Elephant (Loxodonta africana) & 5 & 32 & 81 & 136 & 109 & 200 \\
\hline Gazelle, Grant's (Gazella granti raineyi) & 26 & 27 & 216 & 230 & 223 & 5,800 \\
\hline $\begin{array}{l}\text { Gazelle, Thomson's (Gazella thomsonii } \\
\text { thomsonii) }\end{array}$ & 31 & 36 & 750 & 897 & 823 & 26,000 \\
\hline Giraffe, reticulated (Giraffa reticulata) & 19 & 29 & 90 & 105 & 97 & 2,220 \\
\hline $\begin{array}{l}\text { Hartebeest, Kenya Jackson's (Alcelaphus } \\
\text { buselaphus jacksoni) }\end{array}$ & 31 & 35 & 94 & 104 & 99 & 3,180 \\
\hline Hippopotamus (Hippopotamus amphibius) & 11 & 12 & & & 21 & 200 \\
\hline Hyena, spotted (Crocuta crocuta) & 20 & 34 & & & 25 & 430 \\
\hline Impala (Aepyceros melampus) & 37 & 39 & 697 & 746 & 722 & 27,080 \\
\hline Leopard (Panthera pardus) & 31 & 38 & & & 10 & 310 \\
\hline Lion (Panthera leo) & 7 & 28 & 10 & 18 & 14 & 150 \\
\hline Oryx, beisa (Oryx beisa annectens) & 20 & 22 & 110 & 132 & 121 & 2,560 \\
\hline Ostrich, Somali (Struthio camelus) & 21 & 24 & 31 & 35 & 33 & 730 \\
\hline $\begin{array}{l}\text { Reedbuck (Redunca } r . \text { wardi, } R . \text { fulverufula } \\
\text { chanleri) }\end{array}$ & 21 & 27 & & & 60 & 1,270 \\
\hline Rhinoceros, black (Diceros bicornis) & 13 & 18 & 7 & 9 & 8 & 120 \\
\hline Steinbuck (Raphicerus campestris) & 20 & 33 & & & 90 & 1,800 \\
\hline Warthog (Phacochoerus aethiopicus) & 8 & 13 & & & 225 & 1,800 \\
\hline $\begin{array}{l}\text { Waterbuck (Kobus ellipsiprymnus, } \\
\quad \text { K. defassa) }\end{array}$ & 31 & 38 & 104 & 114 & 109 & 3,540 \\
\hline Zebra, common (Equus burchelli) & 31 & 38 & 131 & 336 & 234 & 6,210 \\
\hline Zebra, Grcvy's (Equus grevyi grevyi) & & 5 & 18 & 100 & 20 & 20 \\
\hline
\end{tabular}


Game Department study on 27 of the ranches in the Rumuruti area indicated that these estimates are reasonably accurate (Hughes, 1968). Population data showing seasonal ranges (resident, and resident plus migratory animals) or means, the number of ranches on which they occur, and total estimated populations are presented in Table 1 for the most important species.

Taking the minimum species population data from the ranchers that made estimates of numbers, there is a minimum of 100,000 game animals of Thomson's gazelle-size and over, which would average out to at least 2,500 head per ranch, with Thomson's gazelle, impala, zebra, Grant's gazelle, warthog, eland, buffalo, oryx and waterbuck in decreasing numerical order. These represent the species which have the greatest economic potential.

An important class of wildlife, often overlooked or assigned secondary importance, are the avian species. While not dealt with comprehensively in this survey, some data were obtained which are pertinent. There is a large number of game birds present in Laikipia, but no attempt was made to determine numbers or actual distribution, although certain significant population factors were noted. The ranchers reported that the game bird populations were very much higher about ten years ago, particularly the helmeted guinea fowl (Numida mitrata), yellownecked spurfowl (Pternistis leucoscepus), and crested and redwinged francolins (Francolinus sephaena and $F$. levaillantia). A severe reduction in numbers was thought to have been caused by a combination of factors, namely drought, flood, and diseases. Most of the ranchers felt that while the game bird populations are not anything like they were, they are in the process of gradually building up again. The slow build-up was attributed to predation and poaching on a small basic breeding population.

\section{Disease Relationships}

The greatest concern of the ranchers regarding wildlife is the fear of disease transmission to their livestock, particularly tick-borne diseases. In spite of this general feeling, however, five of the ranchers had none to negligible disease problems, which they attributed to careful sanitation, prophylaxis and treatment. There is evidence to indicate that many parasites and diseases did not originate with wildlife, but, on the contrary, were transmitted to them by domestic livestock, e.g. rinderpest. However, this does not change the fact that, whether susceptible to certain diseases or not, wildlife may be important reservoirs or carriers of them. Prevention of such diseases in livestock is difficult if prophylaxis does not exist or is not satisfactory, and, of course, treatment of wildlife is not feasible, if possible.

It appears that tick-borne diseases can be adequately controlled with proper tick control that new and modern acaricides can provide. Even if all the wildlife were removed from specified areas, certain soil-borne diseases, such as anthrax, tetanus, blackquarter, Salmonellosis, lymphadenitis, botulism and coccidiosis, would still be almost as prevalent in livestock. On the basis of those diseases attributed to wildlife by the ranchers, it would appear that the most serious threat to livestock is posed by buffalo, with waterbuck a close second, then zebra, eland, impala, Kenya hartebeest, warthog, giraffe, Thomson's gazelle, steinbuck and elephant in order of decreasing accusations.

In an effort to assign an economic value to the contributing costs of wildlife in relation to diseases and their control or treatment, let us assume that one-half the cost of tick control, and onehalf the cost of annual veterinary expenditures, is due to wildlife. If we arbitrarily assume that the average ranch has 3,000 head of cattle, and dips fortnightly at an average cost of 3.5 cents per head per time, the annual cost of dipping is $\$ 2,800$, half of which is $\$ 1,400$. As determined in this study, the average annual veterinary costs are $\$ 958$, half of which is $\$ 479$. Therefore, wildlife may cost the average ranch $\$ 1,879$ annually for disease control.

\section{Forage Competition}

Competition for forage constituted the second largest threat to livestock from wildlife. While the majority of ranchers have a tolerant attitude toward wildlife in reasonable numbers, scasonal influxcs of migratory species were felt to be particularly competitive and/or damaging.

Forage competition was felt to be negligible by eight of the ranchers, one of whom qualified this by stating that this was normally the case with static wildlife populations. Ten ranchers felt that all wildlife species were competitive because the cattle and sheep browsed during the dry seasons, therefore competing with grazers or browsers year-round. Another said that all species were competitive on new grass, and that game took forage on his ranch that would support 150 more cattle at an average value of $\$ 62$ each. Still another reported that the game went after the best stargrass. One rancher felt that all wildlife except giraffe, gerenuk and elephant were in competition with his stock, while another excluded elephant alone from a competitive role.

Zebra were reported by 21 ranchers as competing with livestock, with one stating that zebra eat one and a half times the amount that cattle do, and clean off the grass. Eight ranchers listed impala as being in competition with livestock, two of them limiting this to competition with sheep, and another stating impala competition existed only in certain paddocks. Thomson's gazelle were listed as competitive in eight cases, one with sheep, and two where the grass was short. Buffalo were considered to be in competition in six cases, one specifying that this was only near 


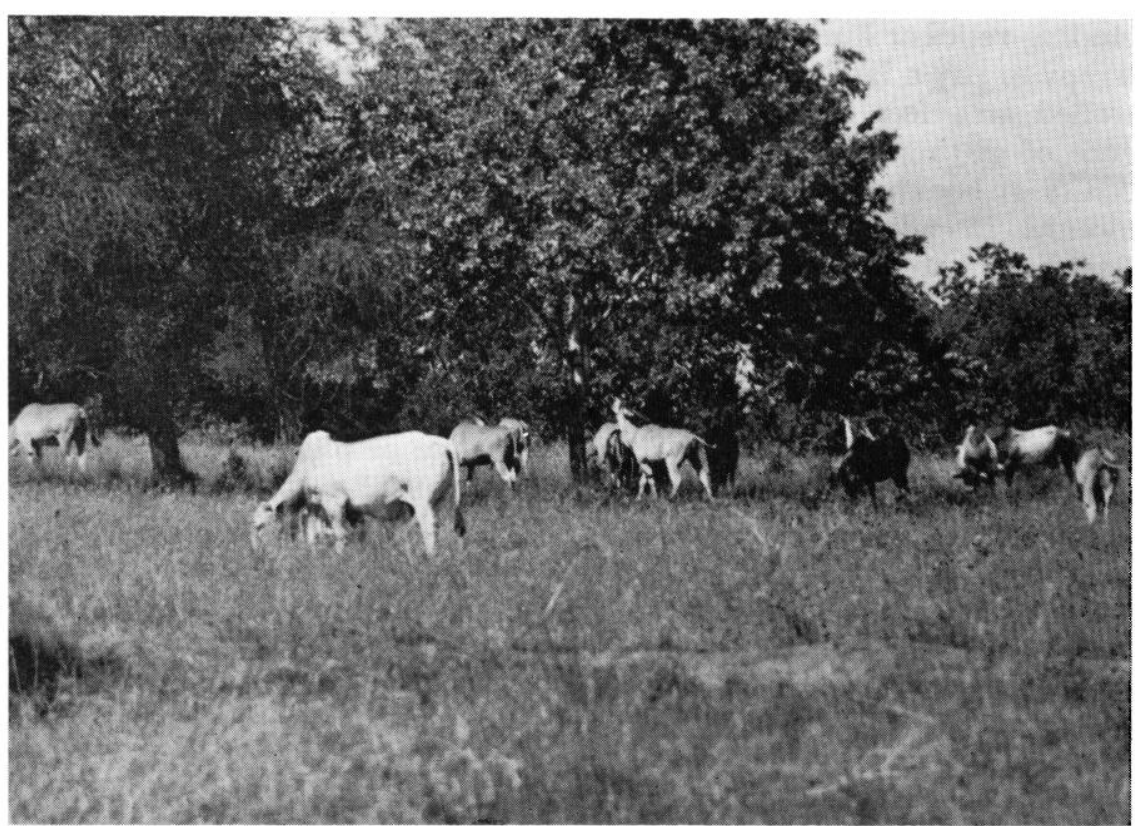

FIG. 5. Wild, free-ranging eland browsing on trees while cattle graze in close association, illustrating compatibility through differential forage preferances.

the forest. Four ranchers listed Kenya hartebeest as competing with livestock, while eland and waterbuck were considered as competition in three cases each, and oryx in two instances. Grant's gazelle and hippo were each listed as competitive in one case. Another rancher felt that all the antelopes were in competition with his cattle.

It is interesting to note that one of the ranchers observed that the lack of bush understory in his paddocks was due, he assumed, to the effect of giraffe. Another rancher was of the opinion that the bush would encroach rapidly into the grassland if all the game was eliminated (Fig. 5). There are minimal data available on the food habits of the various wildlife species, particularly as they differ seasonally, and from one habitat to another. Nevertheless, it may be assumed that the most direct competition is from the grazing ungulates, including those that feed on a mixture of grass and herbaceous dicotyledons, such as buffalo, hartebeest, waterbuck, reedbuck, oryx, Grant's and Thomson's gazelles, zebra, hippo and warthog. Some of the Laikipia species include grass, herbaceous dicots and browse in their diets, namely elephant, rhinoceros, impala, bushbuck and eland; others are principally browsers, such as giraffe and gerenuk. Therefore, it does not appear logical to state that all wildlife, or even all antelopes, are in direct competition with livestock.

Near the end of the rainy season competition should be at a minimum when there is a greater selection of species available and the game is not concentrated. Conversely, competition probably becomes intensified as the dry season progresses and the diversity and quantity of grasses become more limited. At any rate, forage competition may be significant on most ranches, at least seasonally, and from certain species such as zebra on early stages of regrowth.

It is difficult to assess the economic impact of wildlife competition on these ranches, but assuming that the rancher who stated that he could run 150 more steers if it were not for game competition was right, then it is costing him almost $\$ 2,800$ per year (150 head at $\$ 62$ prorated over three and a half years-the age at which steers are generally sold). This is probably an over-estimation, however, since he was already admittedly overstocked. The overall average annual cost of wildlife competition would probably be nearer $\$ 560$.

\section{Damage and Predation}

The third liability of wildlife on the ranches concerns damage, both from the standpoint of physical damage to developments such as fences, waterpoints and crops, and losses through predation. Of these, predation caused the greatest economic losses.

Nine ranchers reported that fence damage was nil or negligible, while 15 reported fence damage to some extent, but not specified as to value. Eleven ranches had fence damage averaging \$288. Elephant caused the most fence damage, followed by buffalo, giraffe, eland, zebra, hartebeest, ostrich, oryx and rhino. Wildlife were reported as responsible for an average of $30 \%$ of the annual fence maintenance costs, or $\$ 84$.

The majority of the game, particularly resident populations, soon get used to the fences and learn about them, although when under stress, such as being chased by dogs when the labor is hunting, or when stampeded, cause some fence damage. There is no doubt that extensive fencing influences the seasonal movements of game, and contributes to the establishment of resident populations of some species which might otherwise move.

Damage to crops was mainly to maize and wheat, although elephants were reported as damaging fruit trees on one ranch. Baboons were the chief culprits in crop damage, with rhino, forest hogs, warthog, porcupine, Thomson's gazelle and squirrel reported specifically. No estimates of value were made pertaining to this type of damage. Baboons were reported to foul waterpoints and supplies by several ranchers.

In regard to predation, 13 ranches reported such losses, but values were not specified. However, predation on 18 other ranches averaged $\$ 1,075$. The main predators and the number of ranches 
reporting losses to them were: hyena, 19; lion, 13; leopard, 13; wild dog, 5; cheetah, 4; and jackal, 4. Losses ranged from one to 100 cattle, and up to 130 sheep and goats annually. One ranch expends $\$ 1,400$ per year on vermin control. The overall annual average predation loss is probably around $\$ 1,960$.

\section{Utilization}

Most of the emphasis one hears about wildlife relationships on ranches pertains to detrimental effects, but the uses made of game are not usually evaluated. Here we will attempt to assess the various ways in which wildlife is used on these ranches, and assign some value to them. According to the Wild Animals Protection Ordinance the landowner has the right to control any wildlife necessary for the protection of his real property. Other than legal sale of hides through a permit from the Game Department the landowner seldom receives any monetary return from animals cropped or taken on control on his property. The meat, however, is generally consumed on the ranch by the staff, labor, and/ or dogs.

Of the 42 ranches, 34 shoot for the pot, that is, for personal consumption. Twenty-eight shoot to supply meat to the labor, and 12 shoot to feed their dogs. Six ranches reported that they shoot primarily for control purposes, the use of the meat being secondary.

One significant source of wildlife income to 20 ranches is the fees and charges that professional hunters and their clients pay the landowners to hunt and camp on the ranches. These hunting privileges vary and are not specifically known, but usually include at least the equivalent of the controlled area fee for any animals shot. This is the sphere of activity which could be expanded considerably, depending on the temperament of the individual landowner, and could provide a relatively high value per animal at little or no cost to himself. Any sportman, in- cluding resident hunters, would be happy to pay a landowner the controlled area fees for the convenience of getting away from the necessity of booking a hunting block months in advance in Nairobi. Based on known values, the estimated average annual income from this source is approximately $\$ 420$.

One of the ranches, besides being an operating cattle enterprise, is the base of operation for one of Kenya's wild animal trappers. With the appropriate capture permits from the Game Department he not only captures animals on his own ranch, but catches such unique animals as reticulated giraffe, Grevy's zebra, and beisa oryx, as well as elephant and common zebra, on various ranches in Laikipia where they occur. The individual ranchers concerned receive an agreed upon fee for each animal captured on their property, and foreign exchange is earned from throughout the world by the sale of these animals to zoological gardens and parks. Captured animals are held in pens on the trapper's ranch for a period of at least two months to adapt them to captivity and a new diet.

When we consider that at least two-thirds of the ranchers shoot game for their labor meat supply, it is obvious that wildlife contributes significantly to the ranch economy; however, assigning a monetary value to this contribution is beset with difficulties. For example, some ranchers stated that the labor would not be supplied with meat if it were not for the game, other than livestock mortalities from accidents or natural causes. Nevertheless, the labor does get this contribution to the maintenance of health, energy and efficiency. This amounts to 638 kilograms of meat per year, worth approximately $\$ 294$, which does not include the game meat eaten in considerable quantities by the ranchers and their families.

Sixteen of the ranches sell zebra hides regularly, receiving up to $\$ 8,400$ annually at $\$ 84$ per hide (this is conservative, as zebra hides are selling above this minimum price), and averaging $\$ 1,829$. There is also a demand for Thomson's gazelle hides, as well as impala and Grant's gazelle, on which 12 ranches received an average annual income of $\$ 1,014$.

\section{Other Wildlife Values and Potentials}

The wildlife values discussed here are those of psychological and aesthetic benefits, or those of such ambiguous criteria as to defy tangible economic description, as well as potentials which either have not been exploited, or in which the exploitation could be expanded.

The aesthetic value of just liking to see the wildlife around their ranches was expressed specifically by 17 ranchers. In addition, the shared pleasures of aesthetic values and comradeship through allowing their friends to come and hunt were reported by 26 ranchers. Seven of the ranchers had wildlife as pets or in captivity in a semidomesticated state, which included buffalo, eland, ostrich, hyrax, oryx, and Thomson's gazelle.

There is a potential income to certain ranches in the aesthetic values of wildlife through game viewing. It is likely that many residents, as well as some tourists who could be contacted through tour agencies, would appreciate the leisurely wildlife observation away from the crowded and competitive-booking commerical game lodge atmosphere. One rancher has initiated such a plan by constructing three bandas (huts) near a reservoir on his ranch, where individuals or families can come to relax and observe his plains game. Another ranch has built a treehouse in the forested foothills near a natural salt lick where elephant, buffalo, bushbuck, and sometimes rhino can be observed. One rancher, a professional hunter himself, caters to people desiring wildlife photography, and allows no shooting on his own ranch. With a relatively small investment and efficient contacts, a good number of the ranchers could realize a con- 
siderable income from this aspect of wildlife alone.

It is conceivable that an intangible value accrues to a rancher from his wildlife populations in that poaching may take some of the pressure off his livestock, which might otherwise suffer more from stock theft and spearing.

A greater potential exists in hunting by sportsmen on the ranches than is now realized. As mentioned previously, some of the ranchers have already derived income from professional hunters and their clients, and this could probably be expanded considerably. As pointed out by Denney (1968), the Game Department kills more animals on control operations than are killed by licensed hunters in Kenya. With closer liaison with the ranchers, the Game Department could refer resident hunters to specific ranches with cropping or control problems on other than dangerous game. The rancher could collect the controlled area fees for such animals killed, and the Game Department would not have to spend the time and money on certain types of control operations, which undoubtedly cost more than the controlled area fees they would lose to the ranchers. While such a program would assist the Game Department and/or the rancher in game control operations, it is undoubtedly true that the control desired would not be attained. Such exploitation of the potential sport hunting business can be conducted under the framework of existing wildlife laws.

The logical assumption that sufficient effect would not be attained through sport hunting in cases requiring game control over an extensive area points directly to the fact that perhaps the greatest potential field of wildlife utilization, and at the same time good game management, lies in the sphere of controlled game cropping, particularly on private land. Protein malnutrition is one of the most important nutritional factors affecting the development of man and econ-
Table 2. Wildlfe potential values on an average Laikipia ranch with current populations and assuming legalization of the sale of game meat.

\begin{tabular}{lcccccr}
\hline \hline & $\begin{array}{c}\text { Mean } \\
\text { Species }\end{array}$ & $\begin{array}{c}\text { Annual } \\
\text { crop }\end{array}$ & $\begin{array}{c}\text { Mean live } \\
\text { weight } \\
(\mathbf{l b} .)\end{array}$ & $\begin{array}{c}\text { Total } \\
\text { carcass } \\
\text { weight } \\
(\mathbf{l b} .)\end{array}$ & $\begin{array}{c}\text { Mean hide } \\
\text { value } \\
(\$)\end{array}$ & $\begin{array}{c}\text { Total } \\
\text { value } \\
(\$)\end{array}$ \\
\hline Buffalo & 120 & 12 & 1,000 & 6,000 & 4.20 & 890.40 \\
Bushbuck & 64 & 6 & 70 & 210 & 3.50 & 50.40 \\
Duiker & 71 & 7 & 20 & 70 & 1.40 & 19.60 \\
Eland & 178 & 18 & 600 & 5,400 & 3.50 & 817.60 \\
Grant's & 223 & 22 & 78 & 858 & 3.50 & 196.00 \\
Hartebeest & 99 & 9 & 200 & 900 & 4.20 & 165.20 \\
Impala & 722 & 72 & 80 & 2,880 & 3.50 & 649.60 \\
Oryx & 121 & 12 & 198 & 1,188 & 2.80 & 198.80 \\
Reedbuck & 60 & 6 & 50 & 150 & 2.10 & 33.60 \\
Steinbuck & 90 & 9 & 18 & 81 & 2.10 & 30.60 \\
Thomson's & 823 & 82 & 32 & 1,312 & 2.80 & 207.20 \\
Warthog & 225 & 22 & 88 & 986 & 1.40 & 165.20 \\
Waterbuck & 109 & 10 & 250 & 1,250 & 5.60 & 229.60 \\
Zebra & 234 & 23 & 330 & 3.795 & 42.00 & $1,498.00$ \\
Total & 3,139 & 310 & & 25,062 & & $5,152.00$ \\
\hline
\end{tabular}

omy in Africa, and the fact that kwashiorkor is common in children in many parts of Kenya is mute testimony to the existence today of protein malnutrition (Mann, 1968). Wildlife undoubtedly provides, through poaching and subsistence hunting, much of the animal protein consumed in many parts of Kenya today, but a biologically sound program of wildlife utilization could supplement or provide the protein requirements of thousands of people until the developing rangeland and livestock schemes come to fruition.

Although none have felt inclined to do so, it is within the discretionary powers of the Chief Game Warden under Kenya laws to authorize the sale of wildlife meat. Before any wildlife is cropped a large amount of biological and ecological data is required. These data would include a complete inventory of the wildlife in the proposed cropping area; determination of migrations and seasonal ranges within the ecological unit of which the cropping area is a part; the species productivity and annual recruitment, as well as natural mortality; the incidence of parasites and diseases; and such population dynamics factors as the sex and age ratios. Quotas established for the individual ranches would have to be prorated according to the area of the ranch in relation to the rest of the ecological unit, and the seasons or amount of time specified species used that ranch, which would insure that several ranchers did not take their "ten per cent" out of the same herd of animals. Such quotas would have to be set by the Game Department for each ranch within a cropping area.

Riney and Kettlitz (1964) reported the impressive potential of wildlife utilization in South Africa, where two to three thousand ranches crop game for an estimated $\$ 1,120,000$ annually. Olafse (1970) found that an impala in Natal is worth $\$ 35$ in terms of meat, hide and horns. If we take mean wildlife population data from Table 1, and only consider those which are of the most economic importance, we can project the potential value of game cropping on an average Laikipia ranch (Table 2). The annual cropping quota is taken as $10 \%$, although such species as buffalo (Bindernagel, 1968), duiker, Grant's 
Table 3. Wildlife related data on an average livestock ranch of 35,000 acres, derived from 42 Laikipia Plateau ranches, 1967-69.

\begin{tabular}{|c|c|c|}
\hline Item & $\begin{array}{c}\text { Costs } \\
(\$)\end{array}$ & $\begin{array}{c}\text { Income } \\
(\$)\end{array}$ \\
\hline \multicolumn{3}{|l|}{ Real or demonstrated values } \\
\hline Diseases attributcd to wildlife & 980 & \\
\hline Tick control and veterinary costs & 1,820 & \\
\hline Predation & 1,288 & \\
\hline Forage competition & 560 & \\
\hline Fence repair and maintenance & 87 & \\
\hline Value of meat for labor & & 294 \\
\hline Fees from professional hunters and clients & & 420 \\
\hline Sales of hides under permit & & 2,822 \\
\hline Buffer value to stock theft and spearing & & + \\
\hline Bush control effect of browsing wildlife & & + \\
\hline $\begin{array}{l}\text { Game viewing, wildlife photography, } \\
\text { aesthetic values }\end{array}$ & & + \\
\hline Subtotal & $\overline{4,735}$ & $3,536+$ \\
\hline \multicolumn{3}{|l|}{ Potential values } \\
\hline Game cropping costs & 1,756 & \\
\hline Predator control (cyanide guns) & 560 & \\
\hline Game cropping $(25,062$ lbs. carcass wt.) & & 5,152 \\
\hline Sport hunting & & 1,400 \\
\hline Intensive wildlife husbandry & & + \\
\hline Subtotal & $\overline{2,316}$ & $6,552+$ \\
\hline Total & 7,051 & $10,088+$ \\
\hline
\end{tabular}

gazelle, hartebeest, impala, steinbuck, Thomson's gazelle (Hvidberg-Hansen, 1969), and warthog could probably stand a heavier cropping and still maintain a static population, depending on the ranch objectives. Carcass weights are considered as $50 \%$ of live weights, though Ledger (1968) demonstrated them to be higher, and the value per pound of carcass weight is calculated at 14 cents, though four Nairobi hotels said they would pay 28 to 60 cents per pound for Thomson's gazelle carcasses. It appears, therefore, that if the sale of wild meat was legal, and that veterinary requirements on sanitation and hygiene could be met, a very tangible income from wildlife could accrue to the ranchers.

Because of the environmental adaptations of game concerning heat stress, water conservation, forage selection and endemic disease resistance, many species can lend themselves well to game farming or game ranching, as demonstrated in the literature by Riney and Kettlitz (1964), Riney (1964), Treus and Kravchenko (1968) and Olafse (1970). The foregoing reports emphasize the possibility of domesticating several species of wildlife, which alone or as a complement to cattle and sheep, could utilize a broader spectrum of habitat conditions and vegetative associations to the benefit of the ranchers.

It would appear that not only can wildlife be compatible with a livestock operation in certain situations, but the potential exists to increase the ranching income through wise and efficient management of the domestic and the wild stock.

\section{Conclusions}

Table 3 represents an average ranch on the Laikipia Plateau, based on mean data extracted from 42 ranches, listing the costs attributed to and the income from wildlife. Certain costs or proportions of them have been chosen arbitrarily, and some data based on the few ranches for which those specific data occurred have been used. Therefore, the inclusion or exclusion of certain costs may be controversial. One half the livestock health cost of tick control and veterinary costs are arbitrarily attributed to wildlife because ranches with little or no appreciable game populations still must dip or spray, and not all of the diseases can be attributed to wildlife. Similarly, the costs duc to disease mortality are considered as half, and the percentage is based on the proportion of disease mortality to overall livestock losses of $3.2 \%$, inasmuch as several ranches had negligible disease mortality. Predation losses are likewise computed on the basis of the proportion of these losses in the overall death losses. It is felt that many of the wildlife liability factors are overstressed here, and possibly some of the benefits are conservative. In fact, many people would consider wildlife as a calculated risk or an act of nature, and therefore not chargeable for implied costs. It is apparent from the data used here that the real or demonstrated values attributed to wildlife do not balance the assumed costs; however, with the legalization of the sale of game meat the potential values can exceed the implied costs of wildlife. This is particularly true if predator control measures, such as cyanide guns, can obviate the inroads of predators. If the rancher did not perform the game cropping himself, he would get a flat fee per head for various species of wildlife without incurring any costs. It is equally obvious that certain species of wildlife, such as elephant, rhino, buffalo, lion, cheetah, leopard, and hyena, will not be tolerated in developed areas and when in conflict with man's immediate interests. The bulk of the data gained in this study has direct application 
to the more developed ranches; however, many of the principles are applicable to developing rangelands. Traditional social structure and local economic conditions, along with land use, condition and trend, must be carefully analyzed and understood before comprehensive wildlife management plans can be drafted and implemented for the developing ranch areas.

In view of the obvious importance of the Laikipia Plateau in Kenya's wildlife future, and the fact that under existing laws the landowner has the power of life or death over wildlife on his land, it is essential that a wildlife management program be drafted for this area specifically. Fundamental to the preparation of such a long range management plan are a complete ecological study of the Laikipia Plateau, including a wildlife survey and the determination of food habits, migrations and seasonal ranges, population dynamics and carrying capacities; basic research on diseases and parasites of livestock and wildlife, and the relationships between them; a pilot game cropping scheme should be initiated to develop the necessary techniques and methods required, and to evaluate the markets.

In addition, the Game Department should strive to improve its public image, particularly with the landowners, through a public relations drive to acquaint and encourage landowners with what they could do to make far more use of the sporting and tourist potentials, which would include a clear explanation of the relevant laws, guidance of fees they charge, and liaison with tourist and hunting agencies.

The Laikipia Plateau offers a location and the opportunity for a unique experiment to determine which wildlife species could be most successfully domesticated. Such a demonstration should be based on a relatively large number of the several species tested, in which newly-caught young would be hand-reared and husbanded in much the same manner as livestock, including herding and paddocking with standard fencing, dipping and inoculating when necessary, culling, castrating, selective breeding of the more tractable individuals, and precise measurements for growth rate and weight gains. Now is the time to initiate such a study, while a broad spectrum of species and numbers is still available. If successful, the ultimate application of such a study would be on unfilled niches of developed ranches and in marginal range areas where disease, parasites, terrain, bush and/or water are the limiting factors for livestock.

\section{Literature Cited}

Allen, G. M. 1939. A checklist of African mammals. Mus. Compar. Zool., Harvard College, Cambridge, Mass. $763 \mathrm{p}$.

Bindernagel, J. 1968. Game cropping in Uganda. Cyclostyled, $200 \mathrm{p}$.

DenNeY, R. N. 1968. The case for intensive wildlife management. $\mathbf{E}$. Afr. Agr. and Forest. J. 2:86-121.

Ellerman, J. R., and T. C. S. MorrisON-ScotT. 1951. Checklist of Palaearctic and Indian mammals, 1758 to 1946. Brit. Mus. Nat. Hist., London. 810 p.

Ellerman, J. R., T. G. S. MorrisonSCOTT, AND R. W. HAYMAN. 1953. Southern African mammals, 1758 to 1951; a reclassification. Brit. Mus. Nat. Hist., London. 363 p.

Hoffman, G. O., D. L. Huss, and B. J. Ragsdale. 1968. Grazing systems for profitable ranching. Texas A and M Univ., Texas Agr. Exten. Serv. MP-896. 7 p.

Hughes, I. 1968. Game population estimates, Rumuruti ranches. Kenya Game Dep., Nairobi. 5 p.

Huidberg-HaNSEN, H. 1969. Contribution to the knowledge of the biology of the Thomson's gazelle and a comparison of its economic potential with the economics of sheep and cattle on a ranch in Kenya. FAO, Rome. Typewritten, $221 \mathrm{p}$.

KENYA MINISTRY OF ECONOMIC Planning and Development. 1965. Agricultural census, large farm areas. Statistics Div., Kenya Min. Econ. Planning and Dev. $49 \mathrm{p}$.

LEDGER, H. P. 1968. Body composition as a basis for a comparative study of some East African mammals. In Comparative nutrition of wild animals. Zool. Soc. London No. 21:289-310.

MANN, I. 1968. The importance of a balanced diet in an expanding urban population. E. Afr. Med. J. 45:1-17.

Morrison, J. 1958. A report on a survey of ranching in the Kenya highlands. Kenya Min. Agr., Nairobi. $42 \mathrm{p}$.

Olafse, J. 1970. Personal communication, Hluhluwe Game Reserve, Natal Province, South Africa.

Riney, T. 1964. The economic use of wildlife in terms of its productivity and its development as an agricultural activity. Trans. FAO African Reg. Mtg. on An. Prod. and Health, Addis Ababa. 1:13 p.

Riney, T., AND W. K. KetTlitz. 1964. Management of large mammals in the Transvaal. Mammalia 28:189248.

Treus, V., and D. Kravchenko. 1968. Methods of rearing and economic utilization of eland in the AskaniyaNova Zoological Park. In Comparative nutrition of wild animals, Zool. Soc. London No. 21:395-411.

William, J. G. 1963. A field guide to the birds of East and Central Africa. Collins, London and Glasgow. 288 p.

\section{REPRINTS}

Reprints of articles appearing in the Journal of Range Management may be obtained only from the author(s); they are not available from the editors or from the Society. Requests for reprints should, therefore, be directed to an author at the address shown for him in the article head or accompanying footnote. 